Yatskevych Inna,

doctor in economics, associate professor,

Odessa Regional Institute of Public Administration of the

National Academy of Public Administration under the President of Ukraine, professor of the department of organization management, Odesa, ORCID ID: 0000-0003-0210-6135, e-mail: innav2018@gmail.com

Kemarska Tamara,

Odessa Regional Institute of Public Administration of the National Academy of Public Administration under the President of Ukraine, lecturer of the department of Ukrainian and foreign languages, Odessa, ORCID ID: 0000-0003-1033-4170, e-mail: ketage438gmail.com

https://doi.org/10.29038/2786-4618-2021-01-129-134

\title{
DIGITALIZATION STRATEGY IN HR MANAGEMENT SYSTEM
}

Annotation. The paper notes the role of digitalization in modern conditions, as well as its importance in the HR management system. It is substantiated that the use of digitalization in the HR management system is a prerequisite for ensuring the future competitiveness and investment attractiveness of an enterprise through its transformation from traditional to technological, i.e. from offline to online. It has been established that the digitalization strategy in the HR management system should contain not only the basic principles and directions, methods and means of achieving the strategic goals of the HR digitalization process, but also reflect the factors and conditions necessary for the implementation of this process. The paper outlines the goal, principles and directions of the digitalization strategy in the HR management system.

Key words: digitalization, personnel, labor productivity, strategy, management, HR.

Яцкевич Инна, доктор экономических наук, доцент, Одесский региональный институт государственного управления Национальной академии государственного управления при Президенте Украины, профессор кафедры менеджмента организации, г. Одесса

Кемарская Тамара, Одесский региональный институт государственного управления Национальной академии государственного управления при Президенте Украины, старший преподаватель кафедры украинского и иностранных языков,

г.Одесса

\section{СТРАТЕГИЯ ДИДЖИТАЛИЗАЦИИ В СИСТЕМЕ УПРАВЛЕНИЯ НR}

\footnotetext{
Аннотация. В работе отмечена роль диджитализации в современных условиях, а также ее важность в системе управления HR. Обосновано, что использование диджитализации в системе управления HR является необходимым условием обеспечения будущей конкурентоспособности и инвестиционной привлекательности предприятия путем его трансформации от традиционной к технологичной т.е. от офлайн к онлайн. Установлено, что стратегия диджитализации в системе управления HR должна содержать не только основные принципы и направления, способы и средства достижения стратегических целей процесса диджитализации HR, но и отражать факторы и условия, необходимые для осуществления данного процесса. В работе обозначено цель, принципы и направления стратегии диджитализации в системе управления HR.
} 
Ключевые слова: диджитализация, персонал, производительность труда, стратегия, управление, HR.

Яцкевич Інна, доктор економічних наук, доцент, Одеський регіональний інститут державного управління Національної академії державного управління при Президентові України, професор кафедри менеджменту організацій,

м. Одеса

Кемарська Тамара,

Одеський регіональний інститут державного управління Національної академії державного управління при Президентові України, старший викладач кафедри украинської і іноземних мов, м.Одеса

\section{СТРАТЕГІЯ ДІДЖИТАЛІЗАЦІЇ В СИСТЕМІ УПРАВЛІННЯ НR}

Анотація: У роботі відзначена роль діджиталізації в сучасних умовах, а так само важливість їі в системі управління HR. Обгрунтовано, що використання діджиталізації в системі управління НR $\epsilon$ необхідною умовою забезпечення майбутньої конкурентоспроможності та інвестиційної привабливості підприємства шляхом іiі трансформації від традиційної до технологічної тобто від офлайн до онлайн.

Метою статті є визначення основних елементів стратегії діджиталізації в системі управління людськими ресурсами та принципів їі побудови.

У роботі визначено, що стратегія діджиталізації в системі управління HR повинна містити не тільки основні принципи та напрями, способи та засоби досягнення стратегічних цілей процесу діджиталізації HR, а й відображати фактори та умови, необхідні для здійснення даного процесу. Відповідно до мети, у роботі зазначено мету (підвищення ефективності діяльності підприємства за рахунок зростання продуктивності праці і розвитку інноваційного потенціалу персоналу) та принципи (націленість на підвищення продуктивності праці, спрямованість на безперервний розвиток потенціалу діджиталізації підприємства, адаптованість) стратегії діджиталізації в системі управління HR.

Визначено і систематизовано основні напрями стратегії діджиталізації в системі управління HR (діджиталізація процесу пошуку й найму співробітників підприємства, діджиталізація процесу навчання й розвитку персоналу, діджиталізація управління, підвищення IT-компетентності співробітників HR-відділу, впровадження цифрових робочих місць, цифровізація робочого середовища).

Проведені дослідження діджиталізації в системі управління HR дали можливість відзначити, що активний прояв та реалізація іiі спостерігається у кадровому адмініструванні, в оцінки персоналу, в автоматизації компенсацій і пільг.

Подальші наукові дослідження пов'язані з визначенням впливу людського фактора на діджиталізацію у підприємстві.

Ключові слова: діджиталізація, персонал, продуктивність праці, стратегія, управління, HR.

Formulation of the problem. The development of socioeconomic relations largely depends on the progress of information and digital technologies. The main characteristic of modern trends in the economy are the accelerated transformations taking place in the development of the information society, the formation of the digital economy and digital transformation of all spheres of activity, i.e. digitalization.

Currently, no type of economic activity can function without the use of modern elements of digitalization. Such technologies are used in the process of information exchange between business entities, distribution and receipt of information, financial transactions, optimization of business processes, etc., as well as in the personnel management system.

The use of digitalization in the personnel management system is one of the criteria for ensuring the competitiveness of enterprises in modern conditions. In this regard, there is a need to develop a digitalization strategy in the human resource management system.

Analysis of recent research and publications. Many works have been devoted to the study of various aspects of digitalization in the human resource management system, namely S. Bardadim, D. 
Belyansky, Y. Bogoyavlenska N. Danilevich, Y. Kasyanenko, V. Likhanova, S. Nevmerzhitska, S. Rudakova, O. Svintsitska, L. Shchetinina and others [1 ... 8].

Highlighting previously unresolved components of a common problem. The purpose of the article is to determine the main elements of the digitalization strategy in the human resource management system and the principles of its construction.

Presentation of the main material. Modern trends in the increasing role of digitalization allow us to conclude that the main role in the digital transformation process is assigned to human resources. Human resource management (hereinafter - HR) is one of the most important guides in the successful operation of an enterprise. The emphasis on the HR of an individual employee, his quality, knowledge, experience, abilities and personality corresponds to a rationalistic approach to personnel management in order to maximize labor productivity $[2 ; 4 ; 6]$.

At the same time, digitalization in the economy has led to a rethinking of HR functions at the operational and strategic levels. Therefore, the use of digitalization in the HR management system is a prerequisite for ensuring the future competitiveness and investment attractiveness of an enterprise through its transformation from traditional to technological, i.e. from offline to online one.

In this regard, it becomes necessary to develop a digitalization strategy in the HR management system, to determine the main elements of this strategy and principles of its construction.

The process of digitalization in the HR management system is becoming a priority task for enterprises, since in ensuring the competitiveness of an enterprise, the main role is assigned to the personnel as a human resource, a carrier of the ability to perceive innovations associated with digital changes, as well as the main source and generator of ideas.

The use of digitalization in the HR management system is currently undergoing continuous improvement, which does not allow for an objective and in-depth analysis of the scientific definition of "digitalization of HR" (digital transformation in the personnel management system). However, it is obvious that digitalization in the HR management system can be applied to any business process, such technologies are of particular importance in the search, recruitment, adaptation, promotion and training of company employees. In other words, all online interactions between the company management and the employee.

It should be noted that digitalization in the HR management system is carried out in order to increase labor productivity and optimize business processes. At the same time, the increase in labor productivity is the result of the success of such processes as recruitment (search) and adaptation of employees, training and development. The optimization of the business process is the improvement of the management process and organization of the production activity of the enterprise, that also affects the development of competition and relationships with customers: the more information you have, the faster you can organize service, sales, communication with customers, etc.

Nowadays, low productivity firms are rapidly losing ground because stock market valuation is determined by advances in intellectual property and services, rather than the quantity of actual goods or capital goods produced.

In the research $[9 \ldots 12]$, it is noted that the growth rate of labor productivity remains low despite the introduction of new technologies, which is due to inconsistency between the levels of technological equipment and the actual amount of work performed, that leads to a number of problems.

The reason for the gap between the level of technological equipment and productivity is that the rate of introduction of new technologies outstrips the speed of digital sensibility of the personnel in the enterprise. In the process of digitalization transformations at enterprises, the approach to the implementation of activities is changing, so there is a need for continuous development, education and professional development of personnel.

The main obstacles to the successful transformation of entrepreneurial activity are staff unavailability, lack of motivation, and a low level of digital sensitivity [9 ... 12].

Note, that the digital sensibility of the personnel must be considered as the ability and readiness of the individual to adapt to changes in entrepreneurial activity caused by digitalization, to perceive and apply them in their activities in order to increase labor productivity.

The main problem of the digitalization process is the need to develop a digitalization development strategy in the field of HR management, as well as in the field of coordinating the activities of employees within the workflow in the context of digitalization. 
The digitalization strategy in the HR management system should contain not only the basic principles and directions, methods and means of achieving the strategic goals of the HR digitalization process, but also reflect the factors and conditions necessary for the implementation of this process. The purpose of this strategy is to increase the efficiency of the enterprise by increasing labor productivity and developing the innovative potential of a personnel.

The enterprise should consider the following principles of the digitalization strategy:

-focus on increasing the productivity of personnel of the enterprise by stimulating the receptiveness to digitalization of individual employees;

- focus on continuous development of enterprise digitalization potential (innovative);

-adaptability, that is, the strategy should respond to changes in the external business environment dictated by the real conditions of the digitalization market and respond quickly to them.

At the same time, the digitalization strategy in the HR management system must be implemented in the context of five main areas:

- digitalization of the process of searching and hiring employees at the enterprise: using social networks to find new employees, analytical and cognitive methods of recruiting, using automated recruiting (hiring) systems, using technologies that provide the possibility of remote interviews;

- digitalization of the personnel training and development process: the ability to quickly acquire new skills and knowledge, independently determine the learning conditions, develop a database of open educational resources, enhance the use of mobile devices and applications;

- digitalization of management: the introduction of technologies based on artificial intelligence in order to provide analytics of the process and learning outcomes, forecasting the success of employees by analyzing the results of interviews, determining the needs of the enterprise in training employees, using cloud technologies to effectively organize network resources and combine them into a single educational network, replacing paper workflow with electronic one, developing information platforms for analyzing labor productivity and the degree of involvement of the employees of the organization;

- increasing the IT competence of the HR department employees implementing the policy in the field of training and advanced training of the company's employees;

- implementation of digital workplaces, digitalization of the working environment: using internal databases to search and exchange information on various projects, developing an integrated platform based on the experience of employees, providing feedback between employees and the management of the enterprise, providing employees with the opportunity to work remotely.

The above mentioned principles make it possible to determine the essence of the digitalization strategy in the HR management system, the implementation of which will ensure the functioning of the HR management system in these areas.

Conclusions and suggestions. It should be noted that digitalization causes profound changes in the structure and nature of doing business, that is primarily manifested in HR. Thus, the digitalization strategy of the HR management system allows enterprises to form a synergistic effect from the alignment of labor resources, jobs, labor relations and digitalization.

It should also be noted that the active manifestation and implementation of digitalization in HR is observed in HR administration. So, many enterprises are already using automated systems that greatly simplify the work of employees of HR departments. Digitalization processes in HR administration take on many functions: they register orders, keep records of employees, control the timeliness of vacations, analyze available personnel data, and so on.

At the same time, the process of digitalization in personnel assessment is gaining momentum, which makes it possible to form a high-quality personnel reserve. With the help of IT solutions, they find the strengths and weaknesses of employees, identify the most qualified personnel, and form individual development plans for employees.

For large enterprises in which the employee motivation system is developed, such digitalization process as the automation of compensation and benefits is actively being implemented. It allows you to 
effectively form a list of benefits, based on the real needs of employees and the financial capabilities of the enterprise.

Further scientific research is related to determining the influence of the human factor on digitalization in the enterprise.

\section{Sources and literature}

1. Данилевич Н., Рудакова С., Щетініна Л., Касяненко Я. Діджіталізація hr-процесів у сучасних реаліях. URL: http://elartu.tntu.edu.ua/bitstream/lib/32485/2/GEB_2020v64n3_Danylevych_NHR_processes_digitization_147-156.pdf (дата звернення: 11.02.2021).

2. Бардадим С. А., Невмержицька С. М. Діджиталізація в сфері управління персоналом організації. Економіка, менеджмент та аудит: сучасні проблеми, перспективи та напрями розвитку : матеріали міжнародної науково-практичної конференції, м. Львів, 22 лютого 2020 року. Львів: ЛЕФ, 2020. С. 55-58.

3. Белянський Д. Діджиталізація аутсорсингу: як по-новому вирішувати звичні завдання. URL: https://mind.ua/openmind/20188945-didzhitalizaciya-autsorsingu-yak-po-novomu-virishuvati-zvichni-zavdannya (дата звернення: 11.02.2021).

4. Свінцицька О.М., Богоявленська Ю.В., Ліханова В.О. Сучасні технології в управлінні розвитком персоналу та їх вплив на ефективність бізнесу. Економіка та управління підприємствами. 2017. Випуск 14. С. 183 - 187. URL: http://www.market-infr.od.ua/journals/2017/14_2017_ukr/34.pdf (дата звернення: 11.02.2021).

5. Рудакова С. Г., Данилевич Н. С., Щетініна Л. В., Касяненко Я. A. Digital HR - майбутнє кадрового адмінстрування. Бізнес І Інформ. 2020.2 №1. $\quad$ С. 265-270. URL: https://doi.org/10.32983/2222-4459-2020-1-265-270 (дата звернення: 11.02.2021).

6. Жуковська В. М. Цифрові технології в управлінні персоналом: сутність, тенденції, розвиток. Науковий вісник Міжнародного гуманітарного університету. 2017. № 2. C. 13-17. URL: http://www.vestnikeconom.mgu.od.ua/journal/2017/27-2-2017/5.pdf (дата звернення: 11.02.2021).

7. Нагибина Н. И., Щукина A. A. HR-Digital: цифровые технологии в управлении человеческими ресурсами. Науковедение. 2017. T. 9. URL: https://webcache.googleusercontent.com/search?q=cache (дата звернення: 11.02.2021).Куйбіда В. С.,

8. Січкаренко К. О. Цифровізація як фактор змін у міжнародних економічних відносинах. Приазовський економічний вісник. 2018. Вип. 3. С. 30-34. URL: http://pev.kpu.zp.ua/journals/2018/3_08_uk/8.pdf (дата звернення: 11.02.2021).

9. Як полегшити життя HR-aм: цифрова трансформація пошуку персоналу. URL: https://prohr.rabota.ua/yak-polegshiti-zhittya-hr-am-tsifrova-transformatsiya-poshuku-personalu/ (дата звернення: 11.02.2021).

10.LIGA HR BAR: діджиталізація професії HRа в Україні. URL: https://biz.ligazakon.net/news/198488_ligahr-bar-ddzhitalzatsya-profes-hra-v-ukran (дата звернення: 11.02.2021).

11. HR діджиталізація в Україні. Тренди. URL: https://shl.com.ua/hr-didzhytalizatsiya-v-ukraini-trendy (дата звернення: 11.02.2021).

12. Digital в HR: инструменты, автоматизация и использование цифровых технологий. URL: https://kiev.hh.ua/article/19271 (дата звернення: 11.02.2021).

\section{References}

1.Danylevych N., Rudakova S., Shhetinina L., Kasjanenko Ja. Didzhitalizacija hr-procesiv u suchasnykh realijakh [Digitalization of hr-processes in modern realities]. Available at: http://elartu.tntu.edu.ua/bitstream/lib/32485/2/GEB_2020v64n3_Danylevych_N-HR_processes_digitization_147156.pdf (accessed: 11.02.2021). [in Ukraine].

2.Bardadym S. A., Nevmerzhycjka S. M. (2020) Didzhytalizacija v sferi upravlinnja personalom orghanizaciji [Digitalization in the field of personnel management of the organization]. Ekonomika, menedzhment ta audyt: suchasni problemy, perspektyvy ta naprjamy rozvytku [Economics, management and audit: current issues, prospects and directions of development]: materialy mizhnarodnoji naukovo-praktychnoji konferenciji, m. Ljviv, 22 ljutogho. Ljviv: LEF Pp. 55-58. [in Ukraine]. 
3.Beljansjkyj D. Didzhytalizacija autsorsynghu: jak po-novomu vyrishuvaty zvychni zavdannja [Digitalization of outsourcing: how to solve common problems in a new way]. URL: https://mind.ua/openmind/20188945didzhitalizaciya-autsorsingu-yak-po-novomu-virishuvati-zvichni-zavdannya (accessed: 11.02.2021). [in Ukraine].

4.Svincycjka O.M., Boghojavlensjka Ju.V., Likhanova V.O. (2017) Suchasni tekhnologhiji v upravlinni rozvytkom personalu ta jikh vplyv na efektyvnistj biznesu [Modern technologies in personnel development management and their impact on business efficiency]. Ekonomika ta upravlinnja pidpryjemstvamy. [Economics and business management]. Vypusk 14. Pp. 183 - 187. Available at: http://www.marketinfr.od.ua/journals/2017/14_2017_ukr/34.pdf (accessed: 11.02.2021). [in Ukraine].

5.Rudakova S. Gh., Danylevych N. S., Shhetinina L. V., Kasjanenko Ja. A.(2020) Digital HR - majbutnje kadrovogho adminstruvannja [Digital HR - the future of personnel administration]. Biznes Inform. [Business Inform]. №1. Pp. 265-270. Available at: https://doi.org/10.32983/2222-4459-2020-1-265-270 (accessed: 11.02.2021). [in Ukraine].

6.Zhukovsjka V. M. (2017) Cyfrovi tekhnologhiji v upravlinni personalom: sutnistj, tendenciji, rozvytok [Digital technologies in personnel management: essence, trends, development]. Naukovyj visnyk Mizhnarodnogho ghumanitarnogho universytetu [Scientific Bulletin of the International Humanities University]. № 2. Pp. $13-17$. Available at: http://www.vestnik-econom.mgu.od.ua/journal/2017/27-2-2017/5.pdf (accessed: 11.02.2021). [in Ukraine].

7.Naghybyna N. Y., Shhukyna A. A. (2017) HR-Digital: cyfrove tekhnologhyy v upravlenyy chelovecheskymy resursamy [HR-Digital: digital technologies in human resource management]. Naukovedenye [Science]. T. 9. Available at L: https://webcache.googleusercontent.com/search?q=cache (accessed: 11.02.2021).

8. Sichkarenko K. O. (2018) Cyfrovizacija jak faktor zmin u mizhnarodnykh ekonomichnykh vidnosynakh [Digitalization as a factor of change in international economic relations]. Pryazovsjkyj ekonomichnyj visnyk [Priazovsky Economic Bulletin]. Vyp. 3. Pp. 30-34. Available at: http://pev.kpu.zp.ua/journals/2018/3_08_uk/8.pdf (accessed: 11.02.2021). [in Ukraine].

9.Jak poleghshyty zhyttja HR-am: cyfrova transformacija poshuku personalu.[ How to make life easier for HR: the digital transformation of staff search]. Available at: https://prohr.rabota.ua/yak-polegshiti-zhittya-hr-am-tsifrovatransformatsiya-poshuku-personalu/ (accessed: 11.02.2021). [in Ukraine].

10. LIGA HR BAR: didzhytalizacija profesiji HRa v Ukrajini. [LIGA HR BAR: digitalization of the HR profession in Ukraine]. Available at: https://biz.ligazakon.net/news/198488_liga-hr-bar-ddzhitalzatsya-profes-hra-vukran (accessed: 11.02.2021). [in Ukraine].

11. HR didzhytalizacija v Ukrajini. Trendy. [HR digitalization in Ukraine. Trends. ]. Available at: https://shl.com.ua/hr-didzhytalizatsiya-v-ukraini-trendy (accessed: 11.02.2021). [in Ukraine].

12. Digital v HR: ynstrumentы, avtomatyzacyja у yspoljzovanye cyfrovыkh tekhnologhyj [Digital in HR: tools, automation and use of digital technologies]. Available at: https://kiev.hh.ua/article/19271 (accessed: 11.02.2021). [in Ukraine]. 